УДК 616.352-089-06 С-605

DOI 10.11603/2414-4533.2020.2.10776

\author{
(СВ. Д. СКРИПКО, П. В. СОЛОМЧАК
}

Івано-Франківський національний медичний університет

\title{
Комплексна оцінка ефективності ексцизійних методів гемороїдектомії
}

\begin{abstract}
Мета роботи: підвищити ефективність лікування хворих на хронічний геморой III-IV ступенів шляхом використання високочастотних струмів при ексцизійних гемороїдектоміях (ГЕ).

Матеріали і методи. В основу дослідження покладено результати комплексного обстеження і лікування 180 пацієнтів із комбінованою ГX III-IV ст., які перебували на стаціонарному лікуванні в хірургічному відділенні Івано-Франківської центральної міської клінічної лікарні з 2012 по 2018 рік. Усім пацієнтам проводили триквадрантну ексцизійну ГЕ. Залежно від проведеного хірургічного лікування всі хворі були поділені на 3 групи. І групі пацієнтів (n=62) проводили класичну закриту ГЕ за Фергюсоном. II групі пацієнтів (n=60) проводили ГЕ за Мілліганом-Морганом монополярною електрокоагуляційною установкою ERBE ACC450. III групі пацієнтів (n=58) проводили ГЕ за Мілліганом-Морганом біполярним високочастотним електрокоагулятором ЕК-300-М1.

Результати досліджень та їх обговорення. ГЕ з використанням високочастотного електрокоагулятора ЕК-300-М1 має ряд переваг, порівняно з стандартною відкритою електрокоагуляційною ГЕ та класичною закритою ГЕ, а саме: скорочення часу оперативного втручання, зменшення тривалості та інтенсивності больового синдрому та потреби в аналгетиках, скорочення термінів тимчасової непрацездатності, зменшення частоти ранніх та пізніх післяопераційних ускладнень, що, у свою чергу, підвищує якість життя хворих.
\end{abstract}

Ключові слова: гемороїдальна хвороба; гемороїдектомія; високочастотний електрокоагулятор; післяопераційні ускладнення.

Постановка проблеми і аналіз останніх досліджень та публікацій. Гемороїдальна хвороба (ГХ) все ще залишається одним із найпоширеніших захворювань людини. За даними ряду авторів, захворюваність на ГХ становить 130-150 на 1000 осіб дорослого населення, а питома вага в структурі колопроктологічних захворювань коливається від 30 до 40 \% [1]. Поширення цього захворювання в індустріально розвинутих країнах набуває характеру епідемії, що призводить до ураження великої кількості людей працездатного віку, тривалої тимчасової непрацездатності тощо [2].

Потрібно зазначити, що гемороїдектомія (ГЕ) це операція, при якій задоволеність пацієнтів низька, хоча це часто виконувана операція в сучасній хірургічній практиці [3]. Основною причиною невдоволення $є$ післяопераційний біль і ускладнення, тому найважливышим питанням ГЕ $є$ контроль над болем та зменшення ранніх і пізніх післяопераційних ускладнень до мінімального рівня [4]. Більшість ускладнень при ГЕ пов'язані з видом хірургічного інструмента, яким видаляється гемороїдальний комплекс, тому хірургічні методи лікування ГХ постійно еволюціонують. Серед нових способів виділяють видалення гемороїдальних вузлів радіохірургічним приладом “Сургитрон”, ультразвуковим (гармонійним) і плазмовим скальпелями, лазером, приладом “Liga Sure” тощо [5, 6].

Останнім часом у світі постійно проводиться велика кількість клінічних досліджень, які порівнюють різні хірургічні інструменти і методики оперативних втручань, що застосовуються при лікуванні ГХ, з метою виявлення найефективнішого і найбезпечнішого [7-9].

Мета роботи: підвищити ефективність лікування хворих на хронічний геморой III-IV ступенів шляхом використання високочастотних струмів при ексцизійних ГЕ.

Матеріали і методи. В основу дослідження покладено результати комплексного обстеження і лікування 180 пацієнтів із комбінованою ГХ ІІІIV ст., які перебували на стаціонарному лікуванні в хірургічному відділенні Івано-Франківської центральної міської клінічної лікарні з 2012 по 2018 рік.

Серед прооперованих хворих переважали чоловіки, їх було 124 із 180 (68,9 \%; 95 \% ДІ 61,6-75,6 \%), відповідно жінок було 56 (31,1%; 95 \% ДІ 24,438,4 \%). Переважання чоловіків ми можемо пояснити тим, що вони більше зайняті в сфері фізичної праці, у них частіше спостерігається порушення режиму харчування і наявність шкідливих звичок. Середній вік обстежених становив 41,3 (35,6-49,3) роки.

Обстежені хворі мали типову симптоматику, характерну для III і IV стадій ГХ. В усіх хворих провідним симптомом було випадання гемороїдальних вузлів, яке спостерігалось у 180 (100\%; 95 \% ДІ 98,0-100,0) хворих. Кровотечу із анального отвору відмічали у 164 (91,1 \%; 95 \% ДІ 86,094,8) пацієнтів, болі в періанальній ділянці - у 87 (48,3 \%; 95 \% ДІ 40,8-55,9), періанальний свербіж - у 56 (31,1 \%; 95 \% ДІ 24,4-38,4). 
Усім пацієнтам проводили триквадрантну ексцизійну ГЕ. Залежно від проведеного хірургічного лікування всі хворі були поділені на 3 групи.

I групі пацієнтів (n=62) проводили класичну закриту ГЕ за Фергюсоном.

II групі пацієнтів (n=60) проводили ГЕ за Мілліганом-Морганом монополярною електрокоагуляційною установкою ERBE ACC450.

III групі пацієнтів $(\mathrm{n}=58)$ проводили ГЕ за Мілліганом-Морганом біполярним високочастотним електрокоагулятором ЕК-300-М1.

Для репрезентативності досліджень ретельно підбирали однотипні групи за всіма параметрами i характеристиками, які могли б вплинути на результати дослідження.

Оцінка безпосередніх результатів проведених операцій включала: оцінку кількості післяопераційних ускладнень, оцінку інтенсивності післяопераційного больового синдрому, тривалість перебування пацієнтів у стаціонарі, термін відновлення працездатності пацієнтів.

Континентний статус оцінювали за допомогою стандартизованих методик згідно зі шкалою "Revised Faecal Incontinence Scale" (RFIS), анонімного опитування "Wexner Constipation Score” (сума балів 0-20), призначеного для виявлення порушень утримання твердих, рідких калових мас і каломазання перед операцією, а також в термін 12 місяців після операції (Wexner S. D., 1993; Sansoni J. et al., 2011; Devesa J.M. et al., 2013). Якість життя пацієнтів після ГЕ ми оцінювали за шкалою якості життя “SF-36”.

Бази даних формували в редакторі "Microsoft Excel 2010” (Microsoft, США). Для їх статистичної обробки використано програмне забезпечення “STATISTICA 10" (StatSoft, CШA).
Результати досліджень та ї обговорення. Одними із основних показників результату проведення хірургічного лікування ГХ є час операції, інтенсивність і тривалість больового синдрому в ранньому післяопераційному періоді та характер і частота післяопераційних ускладнень.

Медіана тривалості оперативних втручань в I групі становила $38,55(33,21 ; 45,54)$ хвилин, в II групі - 23,37 $(19,56 ; 27,47)$ хвилин, а в III групі $18,62(13,32 ; 23,21)$ хвилин. Різниця у всіх трьох групах була достовірно значущою, найменша тривалість операції була у III групі хворих, у якій використовувався високочастотний електрокоагулятор EK 300-M1 ( $\left.<<0,05 ; \mathrm{p}_{1}<0,05\right)$.

На нашу думку, ГЕ, виконана за допомогою високочастотного біполярного електрокоагулятора, технічно потребує менше часу, оскільки забезпечує швидкий і стійкий контроль гемостазу, який не потребує накладання швів, додаткової коагуляції, а також прошивання і перев'язування судинної ніжки.

Динаміка інтенсивності больового синдрому після операцій оцінювалась на 1-7, 14, 30 доби післяопераційного періоду за загальноприйнятою візуально-аналоговою шкалою (ВАШ). При цьому пацієнт фіксував максимальну інтенсивність болю за оцінюваний день (рис. 1).

Із представлених даних видно, що на першу післяопераційну добу у всіх трьох групах різниця не була значущою (p>0,05). Проте у I і II групі висока інтенсивність болю утримувалась протягом перших 7 днів після операції, а у III групі достовірно знижувалась вже з другої післяопераційної доби і у всі наступні дні біль був достовірно нижчим, порівняно з I і II групами $(\mathrm{p}<0,05)$.

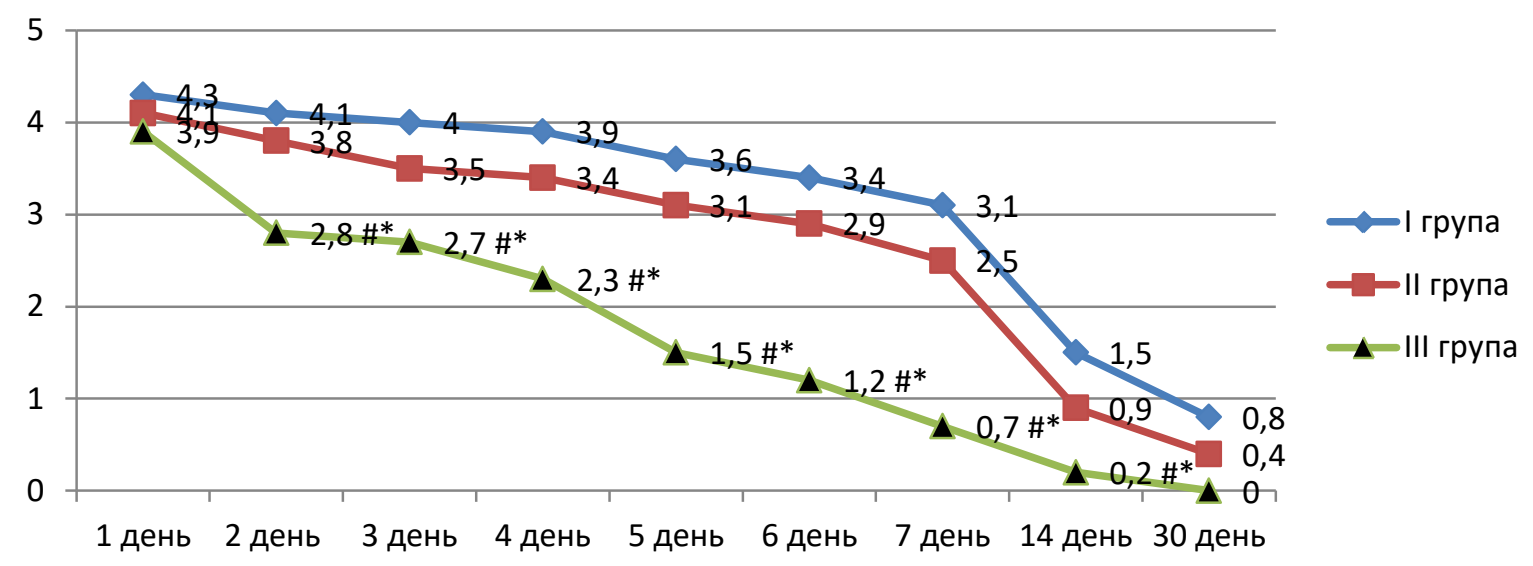

Рис. 1. Динаміка інтенсивності больового синдрому за ВАШ протягом 1 місяця після операції.

Примітки: 1. \# - достовірність різниці показників у II і III групах, порівняно з I групою, p<0,05.

2. * - достовірність різниці показників у III групі, порівняно з II групою, p<0,05. 
Через 30 днів після операції у всіх групах інтенсивність болю була незначною і достовірно не відрізнялась (р>0,05).

Продемонстровану найнижчу інтенсивність болю в III групі можна віднести до переваг виконання операції електрокоагуляційною установкою ЕК-300-М1.

Потребу пацієнтів в аналгетиках (наркотичних і ненаркотичних) ми оцінювали за наступною шкалою: 0 балів - не потребує аналгетиків, 1 бал потребує знеболювання 1 раз на добу, 2 бали - потребує знеболювання 2 рази на добу, 3 бали - потребує знеболювання 3 рази на добу, 4 бали - потребує застосування наркотичних аналгетиків.

Оскільки больовий синдром був найінтенсивніший протягом перших 7 днів після операції, ми оцінювали потребу в аналгетиках протягом цього часу. Дані представлені на рисунку 2.
Аналізуючи потребу в аналгетиках ми виявили, що найнижчою вона була в III групі хворих впродовж усіх 7 днів, порівняно $з$ I і II групами $(\mathrm{p}<0,05)$, що пов'язано з найнижчою інтенсивністю болю в III групі за ВАШ.

Вища інтенсивність болю в I групі пов’язана 3 механічним пошкодженням нервових закінчень аноректальної зони внаслідок накладання швів, а у II групі - з термічним опіком тканин в ділянці рани з подальшим її інфікуванням. У III групі найнижчу інтенсивність болю ми можемо пов'язати $з$ тим, що електрокоагуляційна установка EK-300-M1 спричиняє мінімальне термічне ушкодження тканин і безкровно видаляє гемороїдальні вузли.

Загоєння ран визначалось як повна епітелізація, яку видано при фізикальному огляді. Дані про загоєння ран представлені у таблиці 1.

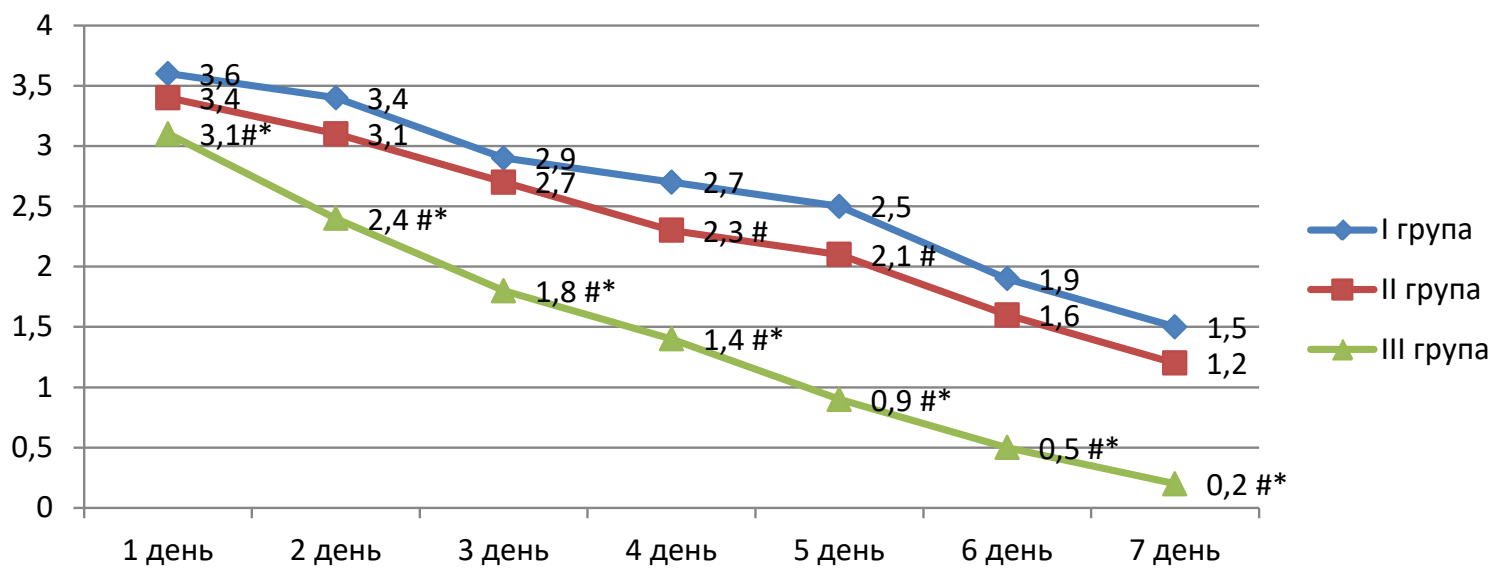

Рис. 2. Потреба в аналгетиках у трьох групах у перший післяопераційний тиждень.

Примітки: 1. \# - достовірність різниці показників у II і ІІІ групах, порівняно з I групою, p<0,05.

2. * - достовірність різниці показників у III групі, порівняно з II групою, p<0,05.

Таблиця 1. Терміни повної епітелізації ран після виконання гемороїдектомії

\begin{tabular}{|c|c|c|c|c|c|c|}
\hline \multirow{2}{*}{ Терміни } & \multicolumn{2}{|r|}{ I група } & \multicolumn{2}{|r|}{ II група } & \multicolumn{2}{|r|}{ III група } \\
\hline & абс. & \%; 95 \% ДІ & абс. & \%; 95 \% ДІ & абс. & \%; 95 \% ДІ \\
\hline До 30 доби & 45 & $72,6(59,8-83,1)$ & 46 & $\begin{array}{c}76,7(64,0-86,6) \\
p>0,05\end{array}$ & 56 & $\begin{array}{c}96,6(88,1-99,6) \\
\mathrm{p}^{<0,05} \\
\mathrm{p}_{1}<0,05\end{array}$ \\
\hline До 40 доби & 14 & $22,6(12,9-35,0)$ & 12 & $\begin{array}{c}20,0(10,8-32,3) \\
\mathrm{p}>0,05\end{array}$ & 2 & $\begin{array}{c}3,4(0,4-11,9) \\
\mathrm{p}<0,05 \\
\mathrm{p}_{1}<0,05 \\
\end{array}$ \\
\hline Після 40 доби & 3 & $4,8(1,0-13,5)$ & 2 & $\begin{array}{c}3,3(0,4-11,5) \\
\quad p>0,05\end{array}$ & 0 & $\begin{array}{c}0,0(0,0-6,2) \\
\mathrm{p}>0,05 \\
\mathrm{p}_{1}>0,05\end{array}$ \\
\hline
\end{tabular}

Примітки: р - достовірність різниці показників у II і III групах, порівняно з І групою;

$\mathrm{p}_{1}$ - достовірність різниці показників у III групі, порівняно з II групою. 
Як видно з таблиці 1, у 96,6 \% (95 \% ДІ 88,199,6) пацієнтів III групи епітелізація відбулась до 30 доби, що достовірно більше, порівняно з I і II групами (p<0,05; $\left.\mathrm{p}_{1}<0,05\right)$. У 22,6 \% (95 \% ДІ 12,935,0) пацієнтів I групи, у 20,0 \% (95 \% ДІ 10,8$32,3)$ пацієнтів II групи і у 3,4 \% (95 \% ДІ 0,4-11,9) пацієнтів ІІІ групи повна епітелізація відбулась до 40 доби (p<0,05; p1<0,05), після 40 доби кількість пацієнтів, у яких відбулась епітелізація, достовірно не відрізнялась (p>0,05; $\left.\mathrm{p}_{1}>0,05\right)$. Швидшу епітелізацію у III групі ми можемо пов'язати з меншим пошкодженням тканин під час використання електрокоагуляційної установки ЕК-300-М1.

Аналізуючи тривалість перебування пацієнтів у стаціонарі і тривалість післяопераційної реабілітації ми встановили, що вони достовірно не відрізнялись в усіх групах (р>0,05). Важливим критерієм оцінки хірургічного лікування хворих з ГХ $€$ середня тривалість втрати працездатності, що визначає соціально-економічну значимість даної проблеми. Терміни трудової реабілітації хворих після операції суттєво відрізнялись: в I групі вони становили 13,5 (12,4; 14,6 ) днів, в II групі - 12,2 $(10,5 ; 13,4)$ днів, в III групі - 8,9 $(7,5 ; 9,7)$ днів $\left(\mathrm{p}<0,05 ; \mathrm{p}_{1}<0,05\right)$.

В значній мірі велика тривалість періоду тимчасової втрати працездатності хворих обумовлена травматичністю рефлексогенної зони, що супроводжується тривалим післяопераційним больовим синдромом, який потребує медикаментозного купірування.

Важливими показниками результату хірургічного лікування будь-якої патології є кількість післяопераційних ускладнень. У нашому дослідженні ми спостерігали за пацієнтами протягом 1 року і фіксували ранні і віддалені післяопераційні ускладнення.

Ранні кровотечі, кровомазання під час перев’язки і дефекації та гіпертермія достовірно частіше спостерігались у II групі хворих, порівняно $з$ I і III групами $\left(\mathrm{p}<0,05 ; \mathrm{p}_{1}<0,05\right)$, що пов'язано з залишенням відкритих післяопераційних ран в анальному каналі з подальшим їх вторинним інфікуванням. Рання затримка сечовипускання достовірно частіше траплялася у I групі, порівняно з II i III групами $(p<0,05)$. Появу гострої затримки сечі після закритої ГЕ ми пояснюємо значною травматичністю оперативного втручання, що зумовлює рефлекторну затримку сечі. Загалом, загальна частота ранніх післяопераційних ускладнень була найвищою у II групі, а найнижчою - у III групі хворих $\left(\mathrm{p}<0,05 ; \mathrm{p}_{1}<0,05\right)$.

Анальні стриктури і тріщини достовірно частіше спостерігались у I групі хворих, порівняно з II i III групами хворих $(\mathrm{p}<0,05)$. Частота пізніх кровотеч і рецидивів ГХ достовірно не відрізнялась

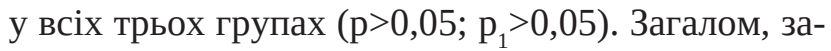
гальна частота пізніх післяопераційних ускладнень була достовірно вищою у I групі хворих $\left(\mathrm{p}<0,05 ; \mathrm{p}_{1}<0,05\right)$.

Континентний статус хворих ми оцінювали за двома опитувальниками: The Revised Faecal Incontinence Scale (RFIS) - діапазон від 0 до 20 балів; Wexner Incontinence Scale (WIS) - діапазон від 0 до 20 балів.

Оцінка менше 4 вказує, що у пацієнта немає нетримання калу або дуже легкі симптоми. Оцінки 4-6 вважаються легкою інконтиненцією, 7-12 - помірною інконтиненцією, а 13 і вище вказують на тяжку інконтиненцію. Континентний статус ми оцінювали через 1 рік після операції.

Континентний статус у I і II групах за опитувальниками RFIS i WIS достовірно не відрізнявся (p>0,05 для обох). У III групі бали були достовірно нижчими, порівняно з I і II групами, за обома опитувальниками ( $<<0,05 ; \mathrm{p}_{1}<0,05$ для обох). Отже, операції з використанням електрокоагулятора EK-300-M1 меншою мірою спричиняють інконтиненцію після ГЕ.

Аналізуючи загальну якість життя хворих у післяопераційному періоді згідно з опитувальником SF-36 ми виявили, що вона була достовірно кращою у III групі хворих $\left(\mathrm{p}<0,05 ; \mathrm{p}_{1}<0,05\right)$ як за фізичним ( $\left.<<0,05 ; \mathrm{p}_{1}<0,05\right)$, так і за психологічним компонентами здоров’я $\left(\mathrm{p}<0,05 ; \mathrm{p}_{1}<0,05\right)$ (рис. 3$)$.

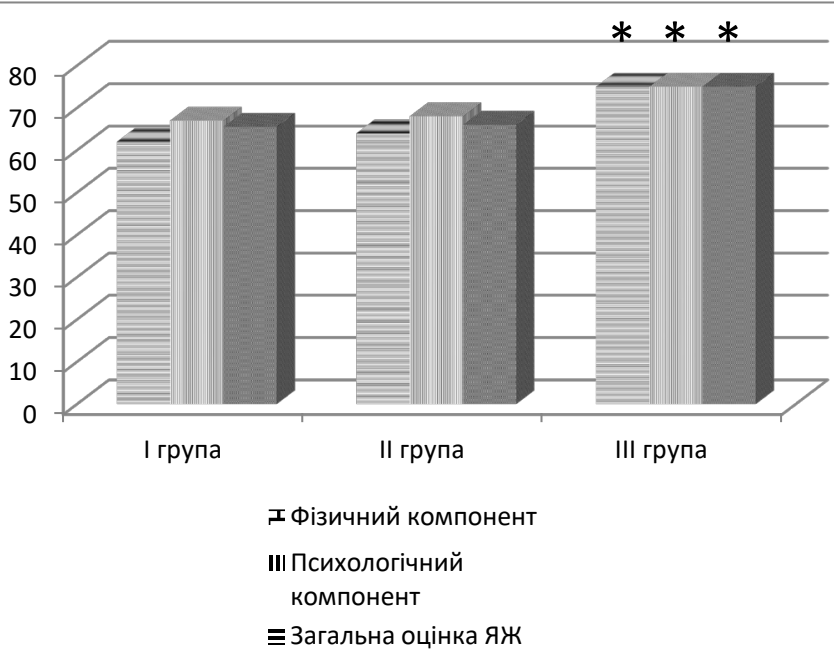

Рис. 3. Якість життя хворих після гемороїдектомії згідно з опитувальником SF-36.

Примітки: 1. \# - достовірність різниці показників у II і ІІІ групах, порівняно з І групою, $\mathrm{p}<0,05$.

2. * - достовірність різниці показників у III групі, порівняно $з$ II групою, $\mathrm{p}<0,05$. 


\section{З ДОСВІДУ РОБОТИ}

Висновки. Отже, ГЕ з використанням високочастотного електрокоагулятора ЕК-300-M1 має ряд переваг, порівняно зі стандартною відкритою електрокоагуляційною ГЕ та класичною закритою ГЕ, а саме: скорочення часу оперативного втручання, зменшення тривалості та інтенсивності больового синдрому та потреби в аналгетиках, скорочення термінів тимчасової непрацездатності, швидша повна епітелізація післяопераційних

\section{СПИСОК ЛІТЕРАТУРИ}

1. Yamana T. Japanese practice guidelines for anal disorders I. Hemorrhoids / T. Yamana // J. Anus Rectum Colon. - 2017. No. 1 - P. 89-99.

2. Systematic review and network meta-analysis comparing clinical outcomes and effectiveness of surgical treatments for haemorrhoids / C. Simillis, S. N. Thoukididou, A. A. Slesser [et al.] // BJS. - 2015. - No. 102. - P. 1603-1618.

3. Hemorrhoidal Disease Symptom Score and Short Health Scale HD: New Tools to Evaluate Symptoms and Health-Related Quality of Life in Hemorrhoidal Disease / H. D. Rorvik, K. Styr, L. Ilum. [et al.] // Dis Colon Rectum. - 2019. - No. 62. - P. 333342.

4. Shaikh A. R. An evaluation of Milligan-Morgan and Ferguson procedures for haemorrhoidectomy at Liaquat University Hospital Jamshoro, Hyderabad, Pakistan / A. R. Shaikh, A. G. Dalwani, N. Soomro // Pak. J. Med. Sci. - 2013. - No. 29. - P. 122-127.

5. Talha A. Ligasure, Harmonic Scalpel versus conventional diathermy in excisional haemorrhoidectomy: a randomized con-

\section{REFERENCES}

1. Yamana, T. (2017). Japanese practice guidelines for anal disorders I. Hemorrhoids. J. Anus Rectum. Colon., 1, 89-99.

2. Simillis, C., Thoukididou, S.N., \& Slesser, A.A. (2015). Systematic review and network meta-analysis comparing clinical outcomes and effectiveness of surgical treatments for haemorrhoids. BJS, 102, 1603-1618.

3. Rorvik, H.D., Styr, K., \& Ilum, L. (2019). Hemorrhoidal disease symptom score and short health scale HD: New tools to evaluate symptoms and health-related uality of life in hemorrhoidal disease. Dis. Colon Rectum., 62, 333-342.

4. Shaikh, A.R., Dalwani, A.G., \& Soomro, N. (2013). An evaluation of Milligan-Morgan and Ferguson procedures for haemorrhoidectomy at Liaquat University Hospital Jamshoro, Hyderabad, Pakistan. Pak. J. Med. Sci., 29, 122-127.

5. Talha, A., Bessa, S., \& Wahab, M.A. (2014). Ligasure, harmonic scalpel versus conventional diathermy in excisional haemorrhoidectomy: a randomized controlled trial. ANZ. J. Surg., ран, зменшення частоти ранніх та пізніх післяопераційних ускладнень, що підвищує якість життя хворих.

Перспективи подальших досліджень. Встановити термічний вплив діатермії та високочастотного біполярного електрокоагулятора на тканини гемороїдального комплексу за допомогою морфологічних досліджень. trolled trial / A. Talha, S. Bessa, M. A. Wahab // ANZ J. Surg. 2014. - No. 87 (4). - P. 252-256.

6. Evaluation and management of hemorrhoids: Italian society of colorectal surgery (SICCR) consensus statement / M. Trompetto, G. Clerico, G. F. Cocorullo [et al.] // Tech. Coloproctol. 2015. - No. 19 (10). - P. 567-575.

7. $\mathrm{Xu} \mathrm{L}$. Ligasure versus Ferguson hemorrhoidectomy in the treatment of hemorrhoids: a meta-analysis of randomized control trials / L. Xu, H. Chen, G. Lin // Surg. Laparosc. Endosc. Percutan. Tech. - 2015. - No. 25. - P. 106-110.

8. Randomized controlled trial of bipolar diathermy vs ultrasonic scalpel for closed hemorrhoidectomy / A. Tsunoda, H. Sada, T. Sugimoto [et al.] // World. J. Gastrointest Surg. - 2011. No. 3. - P. 147-152.

9. Ligasure versus Ferguson hemorrhoidectomy in the treatment of hemorrhoids: a meta-analysis of randomized control trials / L. Xu, H. Chen, G. Lin, Q. Ge // Surg. Laparosc. Endosc. Percutan. Tech. - 2015. - No. 25. - P. 106-110.
87 (4), 252-256.

6. Trompetto, M., Clerico, G., \& Cocorullo, G.F. (2015). Evaluation and management of hemorrhoids: Italian society of colorectal surgery (SICCR) consensus statement. Tech. Coloproctol., 19 (10), 567-575.

7. Xu, L., Chen, H., \& Lin, G. (2015). Ligasure versus Ferguson hemorrhoidectomy in the treatment of hemorrhoids: a metaanalysis of randomized control trials. Surg. Laparosc. Endosc. Percutan. Tech., 25, 106-110.

8. Tsunoda, A., Sada, H., \& Sugimoto, T. (2011). Randomized controlled trial of bipolar diathermy vs ultrasonic scalpel for closed hemorrhoidectomy. World J. Gastrointest. Surg., 3, 147152.

9. Xu, L., Chen, H., Lin, G., \& Ge, Q. (2015). Ligasure versus Ferguson hemorrhoidectomy in the treatment of hemorrhoids: a meta-analysis of randomized control trials. Surg. Laparosc. Endosc. Percutan. Tech., 25, 106-110. 


\author{
V. D. SKRIPKO, P. V. SOLOMCHAK
}

Ivano-Frankivsk National Medical University

\title{
COMPREHENSIVE EVALUATION OF THE EFFECTIVENESS OF EXCISION METHODS OF HEMORRHOIDECTOMY
}

The aim of the work: to increase the effectiveness of treatment of patients with chronic hemorrhoids III-IV degree by using highfrequency currents at excisional hemorrhoidectomy (HE).

Materials and Methods. The study is based on the results of a comprehensive examination and treatment of 180 patients with combined HD stage III-IV, who were hospitalized in the Surgical Department of the Ivano-Frankivsk Central City Clinical Hospital from 2012 to 2018. All patients underwent a three-quadrant excision of HE. Depending on the surgical treatment, all patients were divided into 3 groups. Group 1 of patients $(n=62)$ performed a classic closed HE. Group 2 of patients $(n=60)$ performed a HE on MilliganMorgan monopolar ERBE ACC450 electrocoagulation unit. Group 3 of patients $(n=58)$ underwent the HE on a Milligan-Morgan bipolar EC-300-M1 high frequency electrocoagulator.

Results and Discussion. Therefore, HE using the high-frequency EC-300-M1 electrocoagulator has several advantages over standard open electrocoagulation HE and classical closed HE, namely: reduction of the time of surgery, reduction of duration and intensity of pain syndrome and need for analgesics, short term reducing the frequency of early and late postoperative complications, which in turn improves the quality of life of patients.

Key words: hemorrhoid disease; hemorrhoidectomy; high-frequency electrocoagulator; postoperative complications.

\author{
В. Д. СКРИПКО, П. В. СОЛОМЧАК
}

Ивано-Франковский национальный медицинский университет

\section{КОМПЛЕКСНАЯ ОЦЕНКА ЭФФЕКТИВНОСТИ ЭКСЦИЗИОННЫХ МЕТОДОВ ГЕМОРРОИДЭКТОМИИ}

\begin{abstract}
Цель работы: повысить эффективность лечения больных хроническим геморроем III-IV степеней путем использования высокочастотных токов при эксцизионной геморроидэктомии (ГЭ).

Материалы и методы. В основу исследования положены результаты комплексного обследования и лечения 180 пациентов с комбинированной ГБ III-IV ст., которые находились на стационарном лечении в хирургическом отделении Ивано-Франковской центральной городской клинической больницы с 2012 по 2018 год. Всем пациентам проводили трьохквадрантную эксцизионную ГЭ. В зависимости от проведенного хирургического лечения все больные были поделены на 3 группы. I группе пациентов (n=62) проводили классическую закрытую ГЭ по Фергюсону. II группе пациентов $(\mathrm{n}=60)$ проводили ГЭ по Миллигану-Моргану монополярной электрокоагуляционной установкой ERBE ACC450. III группе пациентов (n=58) проводили ГЭ по Миллигану-Моргану биполярным высокочастотным электрокоагулятором ЕК-300-М1.

Результаты исследований и их обсуждение. ГЭ с использованием высокочастотного электрокоагулятора ЕК-300-М1 имеет ряд преимуществ, по сравнению со стандартной открытой электрокоагуляционной ГЭ и классической закрытой ГЭ, а именно: сокращение времени оперативного вмешательства, уменьшение продолжительности и интенсивности болевого синдрома и потребности в анальгетиках, сокращение сроков временной нетрудоспособности, уменьшение частоты ранних и поздних послеоперационных осложнений, что, в свою очередь, повышает качество жизни больных.
\end{abstract}

Ключевые слова: геморроидальная болезнь; геморроидэктомия; высокочастотный электрокоагулятор; послеоперационные осложнения. 